and one province of Canada. These organizations enabled greater participation in ACRL, provided programs of significance within reasonable traveling distance of members, and offered a focus and voice for the local, state, and regional concerns of academic librarians. This year ACRL strengthened the chapters' ability to serve members through a provision allowing them to offer ACRL continuing education courses and share revenue with the national Association.

9. Three special projects. The Association also underwrote or received outside funding for three special projects. 1) The National Endowment for the Humanities awarded ACRL $\$ 62,423$ for a second series of workshops to encourage humanities programming in academic libraries and the development of grant proposals to fund such programs. Two workshops will be held during the spring of 1983. 2) ACRL also received the $1982 \mathrm{~J}$. Morris Jones Award of $\$ 5,000$ for a project designed by the Bibliographic Instruction Section to duplicate at eight state and regional library association meetings portions of the highly successful 1979 BIS Dal- las Preconference. This project, called Bringing Workshops to Members, aims at increasing the knowledge and skills of librarians involved in user education as well as strengthening state and regional educational programming. 3) To fill one gap in academic library statistics, ACRL headquarters staff is repeating the statistical survey of non-ARL university libraries. Questionnaires were distributed to 91 U.S. and ten Canadian university libraries in late 1982 with publication of the data projected for spring, 1983.

I hope that, after reviewing the accomplishments and commitments of ACRL, you will agree that ACRL has much to contribute to your own personal development and the development of academic/research libraries. In addition, if you have not already done so, I hope you will choose to renew your membership and resolve to be an active participant in Association activities.

Carla J. Stoffle President, ACRL

\title{
ACRL 1982/83 Budget
}

ACRL Summary Budget

\begin{tabular}{|c|c|c|c|}
\hline & $\begin{array}{c}1981 / 82 \\
\text { Budgeted }\end{array}$ & $\begin{array}{c}1981 / 82 \\
\text { Actual }\end{array}$ & $\begin{array}{c}\text { 1982/83 } \\
\text { Budgeted }\end{array}$ \\
\hline Revenue & $\$ 1,580,074$ & $\$ 1,476,697^{*}$ & $\$ 1,390,186$ \\
\hline Expense & $1,579,490$ & $1,282,734$ & $1,429,912$ \\
\hline Net Income & 584 & 193,963 & $(39,726)$ \\
\hline Amount carried forward & 114,746 & 172,994 & 241,317 \\
\hline Balance & $\$ 115,330$ & $\$ 366,957^{\circ}$ & $\$ 201,591 \cdots$ \\
\hline
\end{tabular}

-Estimates provided by the ALA Controller.

*Includes $\$ 98,600$ in deferred liabilities.

$\cdots$ Includes $\$ 76,023$ in deferred liabilities, plus the $\$ 98,600$ from the previous year.

\section{Note: Figures in parentheses are negative amounts.}

At the direction of the Executive Committee, the budget for 1982/83 is being presented with the Choice budget included in the overall ACRL budget instead of being presented separately as in previous years. This more accurately reflects ACRL's fiscal responsibilities and liabilities.

A general overview of the 1982/83 budget is shown in pie-chart form on page 9 . Subsequent articles in $C \& R L$ News will discuss each of the program areas in more detail.

A table showing specific dollar amounts is provided on the following page for your interest. The base dollar amounts for revenues and expenses include funds approved by the Board in previous years for projects extending over more than one fiscal year. The figures are therefore slightly higher than those indicated in the summary table above.

Highlights of the 1982/83 budget include the funding of a statistics project to collect data on non-ARL university libraries, the continuation of the bibliographic instruction liaison project, the funding of a task force to explore the usefulness, feasibility, and format for a third edition of Books for College Libraries, and increased support for chapters and sections. 
REVENUES

\begin{tabular}{lccc}
\hline Activity & $\begin{array}{c}\text { Budgeted } \\
\mathbf{1 9 8 1 / 8 2}\end{array}$ & $\begin{array}{c}\text { Budgeted } \\
\mathbf{1 9 8 2 / 8 3}\end{array}$ & $\begin{array}{c}\text { \% of } \\
\mathbf{1 9 8 2 / 8 3}\end{array}$ \\
\hline Choice & $\$ 810,580$ & $\$ 935,999$ & $63.2 \%$ \\
Membership dues & 192,500 & 193,400 & 13.0 \\
Minneapolis Conference & 189,690 & - & - \\
$C$ URL & 108,078 & 110,225 & 7.4 \\
CURL News & 64,023 & 74,709 & 5.0 \\
NEH Project & 64,549 & 62,423 & 4.2 \\
Continuing Education & 44,600 & 40.500 & 2.7 \\
Preconferences & 58,075 & 39,670 & 2.7 \\
Publications & 7,500 & 18,600 & 1.3 \\
Job Listing Services & 8,100 & 5,850 & .4 \\
Other & 1,600 & 800 & .1 \\
$\quad$ TOTAL & $\$ 1,549,295$ & $\$ 1,482,176$ & $100.0 \%$ \\
\hline
\end{tabular}

EXPENSES

\begin{tabular}{lccc}
\hline Activity & $\begin{array}{c}\text { Budgeted } \\
\mathbf{1 9 8 1 / 8 2}\end{array}$ & $\begin{array}{c}\text { Budgeted } \\
\mathbf{1 9 8 2 / 8 3}\end{array}$ & $\begin{array}{c}\text { \% of } \\
\mathbf{1 9 8 2 / 8 3}\end{array}$ \\
\hline Choice & $\$ 810,570$ & $\$ 898,250$ & $61.5 \%$ \\
CむRL News & 91,511 & 104,199 & 7.1 \\
CURL & 85,683 & 94,245 & 6.5 \\
NEH Project & 64,549 & 62,423 & 4.3 \\
Continuing Education & 44,889 & 49,549 & 3.4 \\
National Conference (Minneapolis) & 189,690 & - & - \\
National Conference (Seattle) & 20,622 & 36,064 & 2.5 \\
Sections & 23,225 & 26,730 & 1.8 \\
RBMS Postconference & 18,250 & 26,627 & 1.8 \\
Committees & 26,452 & 25,773 & 1.7 \\
Chapters & 18,516 & 25,073 & 1.7 \\
Bibliographic Instruction Project & 18,645 & 21,621 & 1.5 \\
Publications & 25,436 & 21,445 & 1.5 \\
Member Services & 20,294 & 16,901 & 1.2 \\
Advisory & 13,056 & 16,670 & 1.1 \\
BIS Postconference & 26,250 & 13,650 & .9 \\
Books for College Libraries 3d & - & 7,079 & .5 \\
Statistics Project & - & 6,827 & .5 \\
Job Listing Services & 9,939 & 5,586 & .4 \\
Discussion Groups & 3,146 & 1,134 & .1 \\
ACRL 100 Project & 1,681 & 518 & - \\
CJCLS Preconference & 13,575 & - & - \\
TOTAL & $\$ 1,525,979$ & $\$ 1,460,364$ & $100.0 \%$ \\
\hline
\end{tabular}




\section{Revenues}

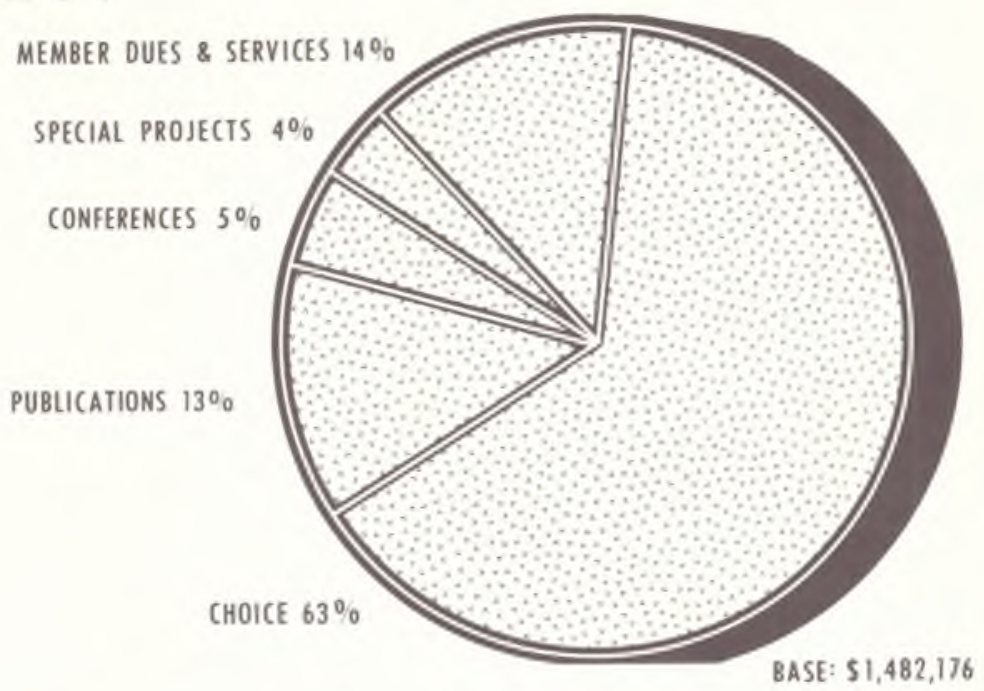

\section{Expenses}

MEMBERSHIP UNITS \& SERVICES $8 \%$

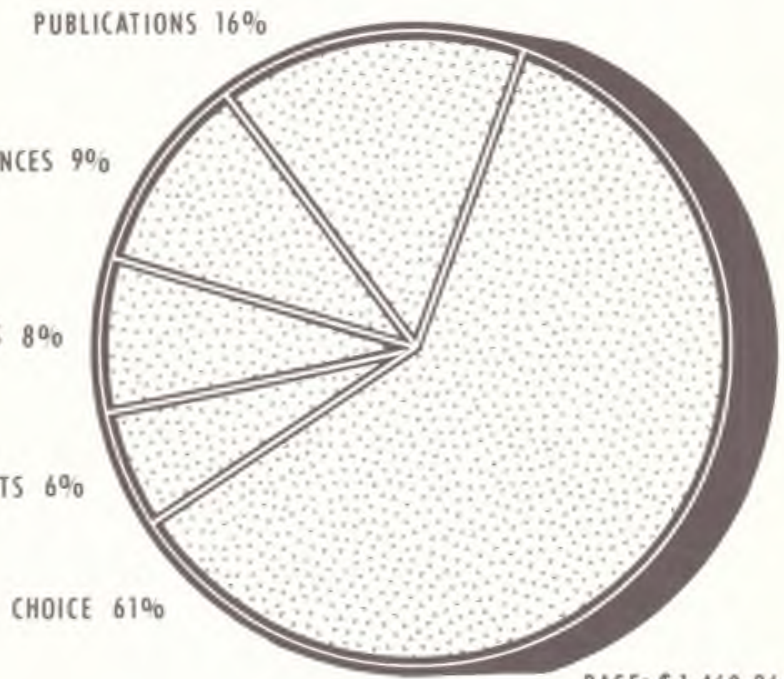

